\title{
The effect of grinding and pelleting on the digestion of Italian ryegrass and timothy by sheep
}

\author{
By D. E. BEEVER, D. F. OSBOURN, S. B. CAMMELL AND R. A. TERRY \\ The Grassland Research Institute, Hurley Maidenhead, Berkshire SL6 5LR
}

(Received 9 June 1980-Accepted 18 May 1981)

\begin{abstract}
1. Primary growths of Italian ryegrass and timothy were harvested in late May, high-temperature dried and either retained in the chopped form or ground through a $2 \mathrm{~mm}$ sieve and pelleted. All diets were fed to four sheep fitted with re-entrant cannulas into the proximal duodenum and measurements of the sites of energy and protein digestion and the synthesis of volatile fatty acids (VFA) and microbial protein were made.

2. Grinding and pelleting significantly reduced rumen digestion of organic matter and structural carbohydrate $(P<0.05)$ and the synthesis of rumen VFA $(P<0.01)$, whilst significantly more digestion occurred in the hind gut, although this was not sufficient to prevent a decline in over-all digestibility on the pelleted diets $(P<0.05)$. The magnitude of all responses was much larger on the Italian ryegrass diet.

3. Net microbial protein synthesis was $15 \%$ less on the pelleted diets but efficiency of microbial protein synthesis was unaffected (mean $188 \mathrm{~g} / \mathrm{kg}$ rumen digested organic matter). Pelleting reduced the degradation of dietary protein from $69 \%$ to $47 \%$, and dietary protein represented significantly more of the total protein flowing to the duodenum on the pelleted diets (chopped $28 \%$, pelleted $41 \%$ ).

4. Over-all, grinding and pelleting reduced total absorbed energy supply by $10 \%$ but increased absorbed protein supply by $15 \%$ which may contribute to some of the improvements seen in the net energy value of pelleted diets.
\end{abstract}

Physical comminution of forage diets by grinding and, generally, pelleting before feeding has been shown to increase their nutritive value, especially those diets of inherently lower quality (Blaxter, 1973). By reducing the particle size of lucerne (Medicago sativa), ryegrass (Lolium perenne) and tall fescue (Festuca arundinacea) Jarrige et al. (1973) demonstrated an inverse relationship between particle size and voluntary food intake. In experiments with perennial ryegrass (Beever et al. 1972; Coehlo da Silva, Seeley, Beever et al. 1972), red clover (Beever, Thomson \& Flarrison, 1971) and lucerne (Thomson et al. 1972; Coehlo da Silva, Seeley, Thomson et al 1972) grinding and pelleting was shown to reduce the extent of ruminal digestion and increase the extent of intestinal digestion of the energy and, to a lesser extent, the nitrogen containing moieties. Such changes in digestion have sometimes been shown to give rise to ar increased faecal output, almost totally attributable to an increased output of cell wall material (Osbourn et al. 1981). However, the size of such increases has been shown to be larger on grasses than legumes and was postulated by Osbourn et al. (1981) to be the result of the higher water soluble carbohydrate content of the former, depressing rumen $\mathrm{pH}$ and the rate: of cell wall digestion within the rumen, and the higher buffering capacity of legumes resisting these changes. The study of Beever et al. (1972) on early (high-soluble-carbohydrate) and late-cut (lower-soluble-carbohydrate) ryegrass tends to confirm this hypothesis.

The work reported in this paper relates to the rumen and intestine digestion of the energy and $\mathbf{N}$ components of a high (Italian ryegrass - Lolium multiflorum, cv. S23) and low (timothy - Phleum pratense, cv. S352) water soluble carbohydrate containing forage, when both were fed chopped or pelleted, and how the physical comminution of dried forages may influence the over-all digestibility of the diet and its nutritive value. 


\section{EX PER IMEN T A L}

\section{Sheep and their management}

Four Suffolk $\times$ Halfbred wethers, 2-3 years old and weighing 45-55 kg were each equipped with a rumen cannula and re-entrant cannulas into the proximal duodenum (Brown et al. 1968). The experiment comprised four periods, with each animal receiving the same diet at any one time. Within each experimental period the animals were housed in metabolism crates in a controlled environment with continuous lighting, but were allowed access to slatted floor resting pens during diet change-over between each period.

\section{Diets}

Primary growths of newly established swards of Italian ryegrass (I) and timothy (T) were harvested in late May, 1974, following application of compound fertilizer $(130 \mathrm{~kg} \mathrm{~N} / \mathrm{ha})$ in March, 1974. The crops were cut with a rotary drum mower and harvested using a double-chop precision forage harvester. After harvest the crop was dried at high temperature in a rotary drier (Swiss-Allmett; inlet temperature $900^{\circ}$ ) and either stored in the chopped (C) form or ground to pass through a $2 \mathrm{~mm}$ sieve and pelleted (P; length $25 \mathrm{~mm}$, diameter $15 \mathrm{~mm}$ ). The diets were fed to the sheep in the order TC, TP, IC and IP. The total daily ration of $1200 \mathrm{~g}$ fresh weight was offered in two equal feeds at 09.00 and 17.00 hours, at which time the animals received $3 \mathrm{~g}$ chromic oxide paper, as an indigestible marker, through the rumen cannula (MacRae \& Armstrong, 1969).

\section{Experimental procedures}

The duration of each experimental period was 6 weeks and all measurements were confined to the last $21 \mathrm{~d}$. Over the first $7 \mathrm{~d}$ of the measurement period a total collection of faecal output was carried out; this was followed immediately by measurement of rumen volatile fatty acid (VFA) production using the method described by Weller et al. (1967).

Sodium acetate $1-{ }^{14} \mathrm{C}$-labelled was infused into the rumen at a constant rate $(3 \mu \mathrm{Ci} / \mathrm{h})$ for $30 \mathrm{~h}$, and small samples of strained rumen liquor were withdrawn manually every hour for the last $24 \mathrm{~h}$. $\mathrm{pH}$ was immediately recorded on each sample before acidification. Three days later a total collection of digesta flowing into the small intestine was carried out for two consecutive $24 \mathrm{~h}$ periods for each animal, using the automatic sampling equipment described by Canaway \& Thomson (1977) and Cammell (1977).

After a further $3 \mathrm{~d}$, fractional outflow rate of rumen water was measured on each sheep by following the level of radioactivity in the rumen liquor after a single dose of $1-{ }^{14} \mathrm{C}$-labelled CrEDTA (Harrison, 1974). The marker was injected immediately after the afternoon feed and samples were removed from the rumen $1 \mathrm{~h}$ later and every hour thereafter until food was offered the following morning.

After a further 3-4 d rumen microbial protein synthesis was measured using the ${ }^{35} \mathrm{~S}$ technique proposed by Beever et al. (1974). $\mathrm{Na}_{2}{ }^{35} \mathrm{SO}_{4}$ was infused intraruminally at a constant rate of $4 \mu \mathrm{Ci} / \mathrm{h}$ for $40 \mathrm{~h}$ and a total collection of duodenal contents was carried out over the last $24 \mathrm{~h}$. Subsequently, approximately $200 \mathrm{ml}$ rumen liquor were removed from each animal for isolation of rumen microbial material.

\section{Sample preparation}

A portion (10\% by weight) of each daily output of faeces was accumulated and the dry matter (DM) content of the resulting sample was determined by drying a small portion at $103^{\circ}$ for $24 \mathrm{~h}$. The remainder of the sample was freeze dried for subsequent analysis. Each individual $24 \mathrm{~h}$ aliquot of duodenal digesta was thoroughly mixed before removal of a small sample for DM determination. The remainder was freeze dried for analysis. 
After freeze drying, all samples were finely ground through a $1 \mathrm{~mm}$ screen, using a small laboratory mill, and then stored at $4^{\circ}$ until required for analysis. Samples of the feeds were taken at the time of weighing out the daily feeds and subsequently ground through a laboratory mill as described previously.

For estimation of total and individual VFA concentrations, all rumen liquor samples were acidified to $\mathrm{pH} 2$ immediately after sampling with $5 \mathrm{M}$-sulphuric acid. Samples of rumen liquor for estimation of $1-^{14} \mathrm{C}$-labelled CrEDTA content were treated with an equal volume of ethanol-water $(50: 50, \mathrm{v} / \mathrm{v})$ as described by Harrison (1974).

The separation of nicrobial material in all rumen and duodenal contents was as described by Beever et al. (1974). All resulting samples, along with portions of the ${ }^{35} \mathrm{~S}$-containing duodenal digesta, were held frozen until required for analysis.

\section{Chemical analyses}

The gross energy ( $\mathrm{GE})$, organic matter $(\mathrm{OM})$, water soluble carbohydrate, cellulose and total $\mathbf{N}$ contents of all diets, duodenal and faecal samples were determined using previously described techniques (Beever, Thomson et al. 1971; Thomson et al. 1972). Cell wall, acid-detergent fibre and lignin content of all samples was determined using the technique of Van Soest (1963) and Van Soest \& Wine (1967), whilst $\mathrm{Cr}_{2} \mathrm{O}_{3}$ contents of the digesta and faecal samples and the administered paper were determined using an automated colorimetric technique (Christian \& Coup, 1954). Soluble N content of all diets was determined using acid-pepsin as described by Beever et al. (1976).

Full amino acid analyses (except methionine) of all food, microbial, duodenal and faecal samples were performed using the technique described by Beever et al. (1978), whilst methionine concentration of these samples was determined after performic acid oxidation (Moore, 1963) as methionine sulphone.

Assay of rumen liquor samples for ${ }^{14} \mathrm{C}$ content of VFA and CrEDTA were as previously described (Harrison, 1974; Beever et al. 1976), whilst rumen VFA concentrations were determined by gas chromatography, as described by Thomson et al. (1978).

${ }^{35} \mathrm{~S}$ content of all samples in relation to the estimation of microbial protein synthesis was determined by liquid scintillation as previously described (Beever et al. 1974).

\section{Calculation of results}

Corrected flow of DM and associated nutrients into the proximal duodenum were calculated using $\mathrm{Cr}_{2} \mathrm{O}_{3}$ as an indigestible marker (MacRae \& Armstrong, 1969). Hemicellulose concentration of food and digesta was calculated as the difference between neutral and acid-detergent-fibre contents. Total VFA production was calculated for each individual hourly sample from a knowledge of the amount of isotope infused and the resulting specific activities of the rumen VFA (Weller et al. 1967; Morant et al. 1978). Total daily production for each animal was obtained by summation of the twenty-four individual estimates.

The proportion of the total protein flowing to the small intestine which was of microbial origin was calculated using the method proposed by Beever et al. (1974), whilst the flow of undegraded food protein to the small intestine was estimated by difference, after an arbitrary allowance had been made for protein of endogenous origin (Coehlo da Silva, Seeley, Beever et al. 1972; Beever et al. 1977).

\section{Statistical assessment}

Owing to the feeding pattern employed, the four experimental treatments were completely confounded with time. Analysis of variance was performed on the results, with removal of the sheep and diet. (time) effects and diet means were compared using the StudentNewman-Keuls test. 
Table 1. Chemical and physical composition of the diets $(\mathrm{g} / \mathrm{kg})$ DM unless otherwise stated).

\begin{tabular}{|c|c|c|c|c|}
\hline & \multicolumn{2}{|c|}{ Italian ryegrass } & \multicolumn{2}{|c|}{ Timothy } \\
\hline & Chopped & Pelleted & Chopped & Pelleted \\
\hline Organic matter & 909 & 915 & 900 & 911 \\
\hline $\begin{array}{l}\text { Water soluble } \\
\text { carbohydrate }\end{array}$ & 207 & 212 & $41 \cdot 0$ & $64 \cdot 4$ \\
\hline Cellulose & 245 & 245 & 297 & 309 \\
\hline Hemicellulose & 237 & 219 & 256 & 256 \\
\hline Lignin & 28 & 32 & 31 & 42 \\
\hline Total nitrogen & 21.5 & $20 \cdot 8$ & $24 \cdot 8$ & 20.9 \\
\hline Pepsin soluble $\mathbf{N}$ & $12 \cdot 7$ & $12 \cdot 5$ & $14 \cdot 1$ & 11.6 \\
\hline $\begin{array}{l}\text { N solubility } \\
(\% \text { total N) }\end{array}$ & $59 \cdot 1$ & $60 \cdot 0$ & 56.9 & 55.5 \\
\hline Total amino acids & 122 & 108 & 133 & 119 \\
\hline $\begin{array}{l}\text { Gross energy } \\
(\mathrm{MJ} / \mathrm{kg} \mathrm{DM})\end{array}$ & $18 \cdot 0$ & $17 \cdot 9$ & $17 \cdot 4$ & 17.8 \\
\hline \multicolumn{5}{|l|}{ *Modulus of: } \\
\hline Fineness & 3.49 & 0.69 & 3.95 & 1.01 \\
\hline Uniformity & $13: 74: 13$ & $0: 4: 96$ & $28: 62: 10$ & $0: 10: 90$ \\
\hline
\end{tabular}

* For fuller description and units, see American Society of Agricultural Engineers (1967).

RESULTS

Chemical composition of the diets

The results presented in Table 1 illustrate the chemical composition of the four diets offered. Differences between the Italian ryegrass and timothy were mainly confined to a higher water soluble carbohydrate and lower cellulose and hemicellulose contents in the former. Grinding and pelleting of the Italian ryegrass diet had little effect on composition, but for the Timothy diet, total $\mathrm{N}$ and total amino acid contents were 16 and $12 \%$ lower respectively on the pelleted compared with the chopped form.

The digestion of gross energy and organic matter

Table 2 relates the quantities of GE and OM consumed and flowing along the alimentary tract of sheep given the four diets. The apparent digestibilities of GE and OM were significantly higher on the Italian ryegrass diets than the timothy diets (GE, $P<0.01 ; \mathrm{OM}$, $P<0.001$ ), whilst the over-all effect of grinding and pelleting resulted in a 5 percentage unit reduction in both GE and OM digestibilities (GE $(P<0.001$; OM, $P<0.001)$. On diet $\mathrm{I}$, grinding and pelleting reduced the proportion of digestible energy which disappeared in the reticulo-rumen from 0.65 to 0.52 , but no such change was noted on diet $T$, and neither the over-all effect nor the interaction term achieved statistical significance. In consequence, post-ruminal digestion of energy was increased by $33 \%$ on diet IP compared with IC, whilst on diet $\mathrm{T}$ the values recorded for both physical forms indicated only a $4 \%$ increase due to pelleting. The lack of flow measurements at the ileum in this study prevented further examination of the relative contribution of the small and large intestine, especially in relation to the elevated energy digestion seen on diet IP. Sites of digestion for OM are also illustrated in Table 2, and indicate similar effects to those already presented for energy. 

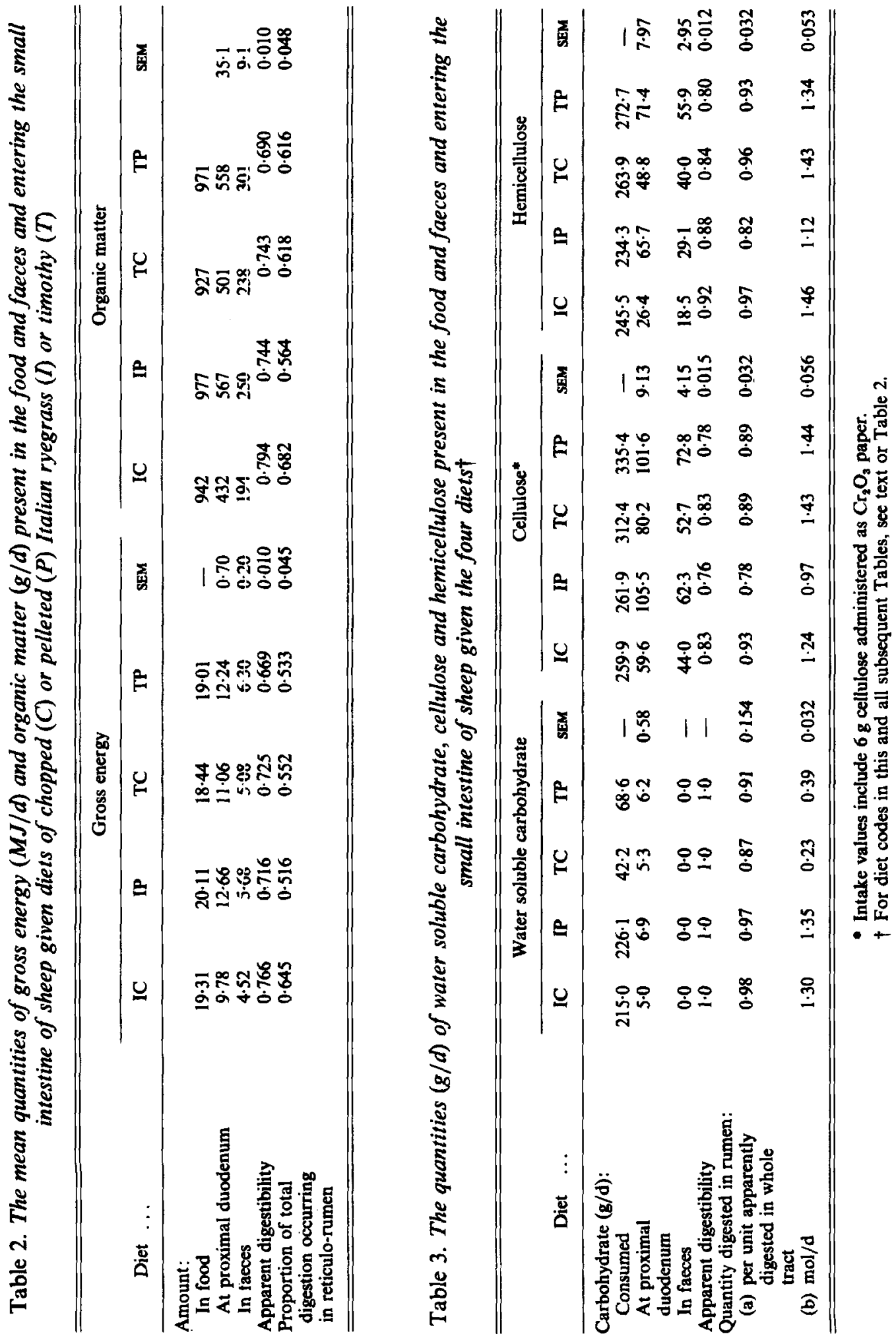
Table 4. The mean quantities of total and individual volatile fatty acids (mol/d) produced in the rumen of sheep given the four diets, the efficiency of conversion of rumen-digested energy $(R D E)$ to $V F A$ energy $(V E)$ and the rate of production of $V F A / m o l$ hexose equivalent $(H E)$ disappearing in the reticulo-rumen

\begin{tabular}{lccccc}
\hline \hline \multicolumn{1}{c}{ Diet $\ldots$} & IC & IP & TC & TP & SEM \\
\hline VFA production (m/d): & & & & & \\
Total & 7.67 & 5.66 & 6.23 & 5.28 & 0.60 \\
Acetic & 5.25 & 3.77 & 4.60 & 3.85 & 0.46 \\
Propionic & 1.70 & 1.27 & 1.19 & 1.06 & 0.12 \\
Butyric & 0.71 & 0.63 & 0.45 & 0.37 & 0.07 \\
Total VE (MJ) & 8.79 & 6.62 & 6.83 & 5.81 & 0.67 \\
VE/RDE (\%) & 92.2 & 95.7 & 92.0 & 86.4 & 11.1 \\
VFA/HE & 1.92 & 1.64 & 2.01 & 1.67 & 0.19 \\
\hline \hline
\end{tabular}

The digestion of forage carbohydrates

Table 3 gives the quantities of water-soluble carbohydrate, cellulose and hemicellulose consumed and flowing along the alimentary tract of sheep given the four diets.

Intake of water-soluble carbohydrate was four times higher in sheep given the Italian ryegrass diets than in those given the timothy diets, but, on average, $93 \%$ of this nutrient was digested in the rumen, irrespective of diet, and there were no differences between diets in the quantities of water soluble carbohydrate flowing at the duodenum. Consequently, on diets IC and IP, the rumen digestion of water-soluble carbohydrate amounted to a mean value of $204 \mathrm{~g} / \mathrm{kg}$ DM consumed and this was significantly higher $(P<0.001)$ than the value of $47 \mathrm{~g} / \mathrm{kg}$ DM observed on diets TC and TP.

Cellulose intake on the timothy diets was $24 \%$ higher than on Italian ryegrass diets, whilst mean over-all cellulose digestibility was similar for both diets $(I, 0.80 ; T, 0.80)$. Grinding and pelleting, however, reduced cellulose digestibility on both diets and the over-all effect was statistically significant (chopped 0.83 , pelleted $0.77 ; P<0.01$ ). Cellulose digestion in the rumen expressed in relation to total cellulose digested in the whole tract tended to be lower on the Italian ryegrass diets $(0.85)$ than the timothy diets $(0.90)$ but this was found to be related to a large reduction in the ruminal digestion of cellulose which occurred on diet IP compared with diet IC, whilst no such response was observed on diet $\mathrm{T}$ (over-all effect - chopped 0.91, pelleted $0.84, P<0.05$ ).

A similar pattern emerged for hemicellulose digestion. Hemicellulose intakes were only slightly higher for diet $T$ than diet $I$, but over-all digestibility was significantly lower $(I, 0.90$; $\mathrm{T}, 0.82 ; P<0.001)$. Grinding and pelleting reduced hemicellulose digestibility on both diets (chopped 0.88 , pelleted $0.84, P<0.01$ ), whilst ruminal digestion of hemicellulose was markedly depressed on diet $I$ as a result of grinding and pelleting compared with a much smaller reduction on diet $T$ (over-all effect - chopped 0.96, pelleted $0.88 P<0.05$ ).

As a consequence of the changes in sites and extent of carbohydrate digestion, the total rumen digestion of carbohydrate constituents varied between 3.7 and $2.9 \mathrm{~mol} / \mathrm{kg}$ DM intake, indicating a significant difference between the two forages (Italian ryegrass 3.54 , timothy $2.99, P<0.01$ ) and between the two physical forms (chopped 3.43, pelleted $3 \cdot 10, P<0.05$ ), although this was, as expected, due entirely to the differences observed between diets IC and IP. 
Table 5. The mean guantities $(\mathrm{g} / \mathrm{d})$ of protein consumed, microbial and undegraded food protein flowing to the small intestine, the apparent efficiencies of microbial protein synthesis and the apparent degradabilities of dietary protein, for sheep given the four diets

\begin{tabular}{lccccc}
\hline Diet $\ldots$ & IC & IP & TC & TP & SEM \\
\hline Total amino acids (g/d): & 121.5 & 115.8 & 136.9 & 125.9 & - \\
$\quad$ Consumed & 139.8 & 160.7 & 147.7 & 159.3 & 7.71 \\
At proximal duodenum: & 87.8 & 80.6 & 87.0 & 74.7 & 6.39 \\
$\quad$ Total & 36.5 & 62.5 & 44.0 & 67.1 & 6.53 \\
$\quad$ Microbial & 172 & 196 & 203 & 180 & 24.9 \\
$\quad$ Undegraded feed & 70.0 & 46.1 & 67.6 & 47.0 & 5.26 \\
Efficiency of microbial prctein \\
synthesis (g/kg RDOM)
\end{tabular}

RDOM, Rumen-digested organic matter.

Table 6. The mean quantities $(\mathrm{g} / \mathrm{d})$ of total nitrogen present in the food and faeces and entering the small intestine of sheep given the four diets

\begin{tabular}{cccccc}
\hline \hline Diet $\ldots$ & IC & IP & TC & TP & SEM \\
\hline Total nitrogen (g/d): & & & & & \\
Consumed & 22.3 & 22.2 & 25.5 & 22.3 & - \\
At proximal duodenum & 27.8 & 31.4 & 29.0 & 30.0 & 1.62 \\
In faeces & 6.96 & 8.20 & 7.00 & 8.56 & 0.182 \\
Apparent digestibility & 0.69 & 0.63 & 0.73 & 0.62 & 0.007 \\
\hline
\end{tabular}

Fiumen production of $V F A$ and microbial protein

Total VFA production varied between 5.3 and $7.7 \mathrm{~mol} / \mathrm{d}$, with the mean value observed on the Italian ryegrass diets being significantly greater $(P<0.05)$ than the mean value observed on the timothy diets. Over-all molar proportions of VFA indicated that the timothy diets had higher acetate (T, $0.73, I, 0.68 ; P<0.01)$ and lower propionate (T, 0.20 , $\mathrm{I}, 0.22)$ and butyrate $(\mathrm{T}, 0.07, \mathrm{I}, 0.10 ; P<0.001)$ levels. Grinding and pelleting had no effect on molar proportions but reduced total VFA production by $26 \%$ on diet $I$ and $16 \%$ on diet $\mathrm{T}$ compared with the respective controls, and the over-all decline due to pelleting was statistically significant: (chopped 6.95 , pelleted, $5.52 \mathrm{~mol} / \mathrm{d} ; P<0.01$ ).

Over-all, the efficiency of conversion of rumen-degraded energy to VFA energy was not significantly affected (mean $91.6 \%$ ) by the treatments imposed, although the yield of VFA/mol hexose equivalent fermented was almost $20 \%$ higher on the chopped diets (chopped 1.97, pelletid 1.66).

The extent of microbial protein synthesis and the apparent degradability of the food protein for the four feeds are given in Table 5. There was a slightly higher intake of total amino acids on diet TC; otherwise, intakes on the other three diets were very similar. All diets showed a net gain of amino acids at the proximal duodenum, ranging from 10 to $45 \mathrm{~g} / \mathrm{d}$, the pelleted dists both showing the larger increases (pelleted 39 , chopped $14 \mathrm{~g} / \mathrm{d}$ ). Despite these increase:; the quantities of microbial protein flowing to the small intestine were quite similar for all four diets, ranging from 74 to $88 \mathrm{~g} / \mathrm{d}$. However, the estimated quantities of dietary protein, after due allowance of an estimate of endogenous protein 
Table 7. The mean quantities $(\mathrm{g} / \mathrm{d})$ of amino acids consumed and entering the small intestine of sheep given the four diets

\begin{tabular}{|c|c|c|c|c|c|c|c|c|c|}
\hline \multirow[b]{2}{*}{ Diet } & \multicolumn{4}{|c|}{ Consumed } & \multicolumn{5}{|c|}{ Entering small intestine } \\
\hline & IC & IP & $\mathrm{TC}$ & TP & IC & IP & TC & TP & SEM \\
\hline Histidine & $2 \cdot 6$ & $2 \cdot 5$ & $2 \cdot 9$ & $2 \cdot 9$ & $3 \cdot 5$ & 3.9 & $3 \cdot 2$ & 4.0 & 0.29 \\
\hline Isoleucine & 6.7 & $6 \cdot 3$ & $7 \cdot 8$ & $7 \cdot 1$ & 9.6 & $11 \cdot 2$ & 9.8 & 11.7 & 0.58 \\
\hline Leucine & $11 \cdot 0$ & $10 \cdot 7$ & $12 \cdot 3$ & 11.5 & $12 \cdot 1$ & $13 \cdot 4$ & $12 \cdot 7$ & 13.7 & 0.62 \\
\hline Lysine & $5 \cdot 2$ & 3.7 & $6 \cdot 2$ & 5.0 & $8 \cdot 6$ & $8 \cdot 6$ & $9 \cdot 2$ & $9 \cdot 4$ & 0.50 \\
\hline Methionine & $3 \cdot 1$ & 2.9 & $3 \cdot 3$ & $2 \cdot 8$ & $2 \cdot 8$ & 3.5 & $3 \cdot 1$ & $3 \cdot 1$ & 0.13 \\
\hline Phenylalanine & $7 \cdot 1$ & 6.8 & 7.9 & $6 \cdot 2$ & 8.9 & $10 \cdot 1$ & $9 \cdot 1$ & $10 \cdot 1$ & 0.49 \\
\hline Threonine & 6.0 & $6 \cdot 0$ & 6.9 & 6.5 & $7 \cdot 4$ & 8.2 & 7.7 & 8.4 & 0.43 \\
\hline Tyrosine & $4 \cdot 6$ & $4 \cdot 0$ & $5 \cdot 0$ & 3.6 & $6 \cdot 4$ & $7 \cdot 1$ & $7 \cdot 1$ & 7.6 & 0.36 \\
\hline Valine & 8.0 & $7 \cdot 7$ & $9 \cdot 4$ & 8.9 & $9 \cdot 7$ & 11.3 & $10 \cdot 5$ & 11.2 & 0.55 \\
\hline Alanine & $9 \cdot 4$ & $9 \cdot 5$ & 10.4 & $10 \cdot 4$ & 10.7 & 12.9 & 11.7 & 11.9 & 0.58 \\
\hline Arginine & $7 \cdot 2$ & $6 \cdot 5$ & 7.7 & $7 \cdot 5$ & 6.8 & 7.9 & $7 \cdot 5$ & 8.4 & 0.42 \\
\hline Aspartic acid & $13 \cdot 3$ & $12 \cdot 4$ & 15.0 & 13.9 & $14 \cdot 2$ & $18 \cdot 0$ & $15 \cdot 5$ & $16 \cdot 2$ & 0.66 \\
\hline Glumatic acid & $17 \cdot 4$ & 17.0 & $19 \cdot 4$ & $18 \cdot 6$ & 17.9 & 19.5 & $18 \cdot 4$ & 19.8 & 0.88 \\
\hline Glycine & $7 \cdot 1$ & 7.1 & 8.2 & 7.8 & 8.8 & 10.5 & 9.3 & 9.8 & 0.61 \\
\hline Proline & $6 \cdot 7$ & $6 \cdot 7$ & 7.7 & 6.0 & 5.7 & 6.6 & $6 \cdot 2$ & 6.8 & 0.39 \\
\hline Serine & $6 \cdot 0$ & $6 \cdot 0$ & 6.5 & $6 \cdot 3$ & 6.7 & 7.8 & 6.9 & 7.6 & 0.44 \\
\hline Total & 121.5 & 115.8 & 136.9 & 125.9 & 139.8 & $160 \cdot 7$ & 147.7 & 159.3 & $7 \cdot 71$ \\
\hline
\end{tabular}

secretion, showed increases of approximately $60 \%$ on the two pelleted diets $(64.6 \mathrm{~g} / \mathrm{d})$ compared with the two chopped diets $(40.4 \mathrm{~g} / \mathrm{d}, P<0.01)$, an increase which was large enough to account for the increased supply of protein to the small intestine of sheep given the pelleted diets. Whilst apparent degradability of feed protein in the rumen was reduced from $69 \%$ to $47 \%$ as a result of pelleting, the response being of similar magnitude on both forages, no statistically significant differences between the two forage species were noted.

Efficiency of microbial protein synthesis in relation to $\mathrm{OM}$ digestion in the rumen ranged from 172 to $203 \mathrm{~g} / \mathrm{kg}$ rumen-digested OM but neither the differences due to forage type nor physical form were found to be statistically significant.

\section{The digestion, flow and composition of amino acids}

All individual amino acids were present in greater amounts at the duodenum than in the corresponding food (Table 7) with the exception of methionine and proline on the two chopped diets and arginine on diet TC, where losses of varying magnitude were observed. The gains noted, however, were generally larger on the pelleted diets, and this led to a greater flow of total amino acids on these two diets compared with the two chopped diets $(P<0.05)$. Of the individual amino acids, only alanine failed to exhibit a statistically significant response due to pelleting when the amount flowing to the small intestine was compared with the amount consumed. For tyrosine, phenylalanine, methionine and aspartate and for isoleucine, lysine, arginine and proline respectively the responses were statistically significant at the 0.1 and $1.0 \%$ levels, whilst for all other amino acids, except alanine, the response due to pelleting was statistically significant at the $5 \%$ level.

In relation to the two forages examined, only aspartate showed a significant response to amino acid flow in relation to the amounts consumed (Italian ryegrass $>$ timothy; $P<0.05)$.

The compostion of the dietary protein with respect to individual amino acids was remarkably similar for the four diets, with the possible exceptions of lysine, which was 
approximately $20 \%$ lower on the pelleted diets compared with the chopped diets, and alanine and serine which showed increases of between 7 and $11 \%$ on the pelleted diets. Differences between the two varieties were more difficult to identify, with perhaps the $10 \%$ increase in valine on the timothy diets being the only consistent trend worthy of mention.

Amino acid composition of duodenal protein was again remarkably similar, with the only effects of pelleting being confined to isoleucine (chopped $6.8 \%$ of total, pelleted $7.2 \%$ of total; $P<0.01$ ), and lysine (chopped 6.2 , pelleted 5.6; $P<0.001$ ), the latter being a probable reflection of the reduced lysine intake on the pelleted diets. In relation to differences between the two varieties, duodenal protein arising from animals given diet $\mathbf{I}$ was significantly richer in serine $(P<0.05)$ but poorer in lysine $(P<0.01)$ and arginine $(P<0.01)$.

\section{Rumen factors}

The mean fractional outflow rates of water for the four diets ranged from 0.072 to $0.082 / \mathrm{h}$. There were no differences between the two forage varieties examined (Italian ryegrass $0.078 / \mathrm{h}$; timothy $0.075 / \mathrm{h}$ ) but in relation to physical form, the process of grinding and pelleting led to an ove:-all increase of $11 \%$ (chopped $0.073 / \mathrm{h} ;$ pelleted $0.081 / \mathrm{h}$ ), although this difference failed to achieve statistical significance.

Values for the $\mathrm{pH}$ of the rumen liquor of sheep given the two chopped diets showed that following the morning feed, only small declines were observed, with, on average, the values for diet IC being 0.5 units lower than diet TC. This difference was accentuated following the afternoon feed, with a steeper decline on diet IC to give a minimum value of 5.8 approximately $3 \mathrm{~h}$ post feeding. Diet TC on the other hand exhibited a less dramatic decline to a pH of 6.3, which did not occur until $6 \mathrm{~h}$ post feeding. Thereafter, both diets showed steady increases overnight to give pre-morning feed values of 6.7 and 7.2 respectively.

Values for the two pelleted diets were very similar to those recorded for diet IC, with the exception of steeper declines immediately following the afternoon feed to minimum values of 5.65 and 5.6i0 (diets IP and TP respectively) which were noted 1 and $3 \mathrm{~h}$ post feeding respectively. Thereafter $\mathrm{pH}$ rose gradually to achieve pre-feeding values of $7.0 \mathrm{in}$ both instances.

\section{DISCUSSION}

Blaxter (1973) has drawn attention to the effect that grinding and pelleting of dried forage may have on the chemical composition of the resultant diet and Wainman \& Blaxter (1972), assuming no loss of ash reported an $8 \%$ loss of $\mathrm{OM}$, an $11 \%$ loss of carbohydrate and a corresponding increase in protein content as a consequence of the physical processing of forage. The results obtained in the present study indicated no such loss of organic matter, but total $\mathrm{N}$ contents were 3 and $16 \%$ lower on the Italian and Timothy pellets respectively compared with the corresponding chopped diets. Similarly, both pelleted diets had $11 \%$ less total amino acids than the corresponding chopped diets, but higher lignin values, suggesting that some leaf loss may have occurred during grinding and pelleting. On both pelleted diets, lysine contents were markedly reduced, which suggests that heat generated during grinding and pelleting may have led to the formation of Maillard complexes (Bjarnson \& Carpenter, 1969, 1970).

\section{Rumen digestion}

The results obtained in the present study are in general agreement with those obtained earlier by Beever, Thomson \& Harrison (1971); Beever et al. (1972) and Coehlo da Silva, Seeley, Thomson et al. (1972). The net extent of rumen digestion is a function of the potential degradability of the individual nutrients (Wilkins, 1969; Black et al. 1980/81), the 
Table 8. The calculated yields of volatile fatty acids $(V F A)$ from the ruminal degradation of the carbohydrate $(\mathrm{CHO})$ and protein fractions of the four diets.

(Values based on $1.0 \mathrm{~kg}$ dry matter intake/d)

\begin{tabular}{lcccc}
\hline \hline \multicolumn{1}{c}{ Diet $\ldots$} & IC & IP & TC & TP \\
\hline Rumen VFA arising from: & & & & \\
$\quad$ Water soluble CHO digestion & 1.94 & 1.97 & 0.34 & 0.56 \\
Structural CHO digestion & 4.53 & 3.41 & 4.84 & 4.55 \\
$\quad$ Protein digestion & 0.78 & 0.47 & 0.85 & 0.53 \\
Total & 7.25 & 5.85 & 6.03 & 5.64 \\
Observed & 7.40 & 5.30 & 6.05 & 4.95 \\
Percentage accounted for & 98.0 & 110.4 & 99.7 & 113.9 \\
Origin of depression due to pelleting (\% of total) & & & \\
(based on calculated yield of VFA) & - & -2 & - & -56 \\
Water soluble CHO & - & +80 & - & +74 \\
Structural CHO & - & +22 & - & +82 \\
Protein & & &
\end{tabular}

fermentation rate within the rumen and the fractional outflow (passage) rate of nutrients from the rumen. It is quite easy to conceive that the grinding and pelleting of a forage, with an associated decrease in particle size, will enhance both fermentation and fractional outflow rates, and results of Blaxter et al. (1956), Rodriguez \& Allen (1960) and Moore (1964) tend to confirm this. Such measurements were not made in this study, and although the fractional outflow rate of water was $11 \%$ higher on the pelleted diets than the chopped diets, it is not possible to draw any conclusions from these results about the fractional outflow ratès of particulate matter. Despite the lack of knowledge of these processes, VFA production was markedly reduced on the pelleted diets, with the size of the decrease being much larger on the Italian ryegrass. From these results it would appear reasonable to conclude that over all, the elevated flow of undigested food OM to the small intestine had a much larger effect on rumen function than did the possibility of elevated fermentation rates.

To understand the origin of the reductions in VFA production it is necessary to consider, on the basis of the observed extents of rumen degradation of the various dietary nutrients and the stoichiometric yields of VFA (Baldwin et al. 1970), the likely yields of VFA from each nutrient. These results are presented in Table 8. Using this approach, the calculated yields of VFA accounted for between 98 and $114 \%$ of the observed yields, which in itself was an encouraging result. On the Italian ryegrass, VFA arising from structural carbohydrate digestion amounted to $62 \%$ of total observed VFA production, whilst a value of $86 \%$ was observed on the timothy diet, and it was found that $80 \%$ of the depression in VFA production caused by grinding and pelleting of the Italian ryegrass could be accounted for by a reduction in structural carbohydrate digestion. Owing to smaller depressions in VFA production and structural carbohydrate digestion on the timothy diet, the position was less clear.

The over-predictions of total VFA production occurred on the pelleted diets. These could be resolved on the basis that the shifts in rumen fermentation seen on these diets may have significantly altered the stoichiometric relationships, with an increased proportion of the digested nutrients being directly incorporated into cell synthesis, instead of undergoing fermentation with an associated production of VFA (Maeng \& Baldwin, 1975).

Whilst VFA production declined in relation to the reduced rumen degradation of structural carbohydrates, it would appear that this was not related to any significant reductions in microbial activity. On average, pelleting reduced net microbial protein 
Table 9. Calculated flow $(\mathrm{g} / \mathrm{d})$ of organic matter $(O M)$, microbial and non-microbial $O M$, fibre and undegriaded dietary protein to the duodenum of sheep given the four diets

Values based on $1 \mathrm{~kg}$ organic matter/d)

\begin{tabular}{lcccccc}
\hline \hline Diet $\quad \ldots$ & IC & IP & $\begin{array}{c}\text { Response } \\
\text { due to } \\
\text { pelleting }\end{array}$ & TC & TP & $\begin{array}{c}\text { Response } \\
\text { due to } \\
\text { pelleting }\end{array}$ \\
\hline Organic matter & 459 & 580 & +121 & 540 & 575 & +35 \\
Microbial OM & 168 & 149 & -19 & 170 & 139 & -31 \\
Non microbial OM & 291 & 431 & +140 & 370 & 436 & +66 \\
Fibre & 91 & 175 & +84 & 139 & 178 & +39 \\
Undegraded & 39 & 64 & +25 & 48 & 69 & +21 \\
dietary protein & & & & & & \\
\hline
\end{tabular}

synthesis by $14 \%$, a1 equalized intakes, but the values derived for efficiency of microbial synthesis did not suggest any impairment in growth per unit of substrate available, supporting the earlier suggestion that changes in fractional outflow rates more than fermentation rates are likely to be the major contribution to the over-all reduction in rumen digestion seen on pelleted diets.

Whilst both diets showed depressions in net rumen fermentation of structural carbohydrates as a result of grinding and pelleting, the size of the response was much greater on the Italian ryegrass. Osbourn et al. (1976) in measuring the depression in over-all digestibility due to grinding and pelleting suggested that the higher water soluble carbohydrate content of ryegrass, in particular Italian ryegrass, may be responsible for the much larger effects seen on such diets compared with the results obtained for timothy or lucerne. Within the present s:udy, almost five times more water soluble carbohydrate was digested in the rumen of sheep given Italian ryegrass compared with timothy and the rapid fermentation of these carbohydrates to VFA would give rise to more rapid declines in $\mathrm{pH}$ post feeding. The limited information on rumen $\mathrm{pH}$ available from this study tends to confirm this suggestion, and as lower $\mathrm{pH}$ values have been shown to reduce cellulolytic activity (Balch, 195C; Campling et al. 1963), this may offer an explanation for the larger depression in structural carbohydrate digestion seen on the pelleted Italian ryegrass.

\section{Hind-gut and over-all digestion}

Turning attention tc the digestion of nutrients in the small and large intestines, it follows from the previous section that a large proportion of any increased $O M$ flow to the duodenum on pelleted diets can be accounted for as undigested structural carbohydrate. On the Italian ryegrass diet, at equalized OM intakes of $1 \mathrm{~kg} / \mathrm{d}$ (see Table 9), an extra $121 \mathrm{~g}$ OM flowed to the intestines, of which $84 \mathrm{~g}$ was calculated to be as extra structural carbohydrate, equivalent to $69 \%$ of the total increase. This value agrees closely with the values of 66 and $70 \%$ calculated by Beever et al. (1972) and Thomson et al. (1972). The situation was less conclusive on the timothy diet, however, with an extra $35 \mathrm{~g} \mathrm{OM} / \mathrm{d}$ being accompanied by an extra $39 \mathrm{~g}$ structural carbohydrate. However, if the depression in microbial protein flow to the small intestine on diet TP is taken into account, and assuming that microbial protain constitutes approximately $55 \%$ of microbial OM (Black et al. 1980/81), then it car. be seen from Table 9 that non-microbial OM (presumably analagous with undegraded dietary OM) flow was $66 \mathrm{~g} / \mathrm{d}$ greater on diet TP compared with diet TC. Of this, $59 \%$ could be accounted for as structural carbohydrate, with undegraded dietary protein accounting for $32 \%$. In a similar way, non microbial OM flow on IP was calculated 
Table 10. The calculated mean quantities of potentially-digestible fibre consumed, at the proximal duodenum, and present in the faeces of sheep given the four diets

(Values taken from Table 3 and based on $1 \mathrm{~kg}$ organic matter intake/d. For details of calculations see p. 368)

\begin{tabular}{|c|c|c|c|c|}
\hline Diet & IC & IP & TC & TP \\
\hline \multicolumn{5}{|c|}{ Potentially digestible fibre $(\mathrm{g} / \mathrm{d})$} \\
\hline Consumed & 470 & 445 & 521 & 525 \\
\hline At proximal duodenum & 25 & 112 & 38 & 77 \\
\hline In faeces & Nil & 31 & Nil & 31 \\
\hline
\end{tabular}

to be $140 \mathrm{~g} / \mathrm{d}$ greater than for diet IC, and in this situation, structural carbohydrate $(60 \%)$ and dietary protein $(18 \%)$ collectively accounted for approximately $80 \%$ of the total increase. The origin of the remaining OM (up to $30 \mathrm{~g} / \mathrm{d}$ on diet IP) is difficult to reconcile. An extra supply of water soluble carbohydrate can be eliminated (Table 3) but the possibility of elevated flows of $\alpha$-linked glucose polymer (Beever et al. 1972) or lipid (Outen et al. 1975) cannot be ignored.

If it is assumed that at the relatively low level of feeding employed in this study the structural carbohydrate present in the faeces of the animals given the two chopped diets represents the indigestible fibre function, whilst the amount digested represents the potentially digestible fibre component of the diet (Wilkins, 1969), and that the relative proportions of each in the diets as fed were unaffected by grinding and pelleting, then it is possible to calculate the quantitative significance of post-rumen fibre digestion (see Table 10). Thus, on the two chopped diets, $94 \%$ of the potentially digestible fibre was digested in the rumen, but pelleting reduced this to $85 \%$ (diet TP) and $75 \%$ (diet IP). Within the intestines, both pelleted diets showed an increase in fibre digestion but the extent of digestion of the potentially digestible fibre within the hind-gut fell from the theoretical maximum of 1.00 to 0.72 (IP) and 0.60 (TP). These results indicate that the hind-gut can compensate for the reduced rumen digestion of fibre but in this study with two grasses this increase was not sufficient to prevent an elevated faecal output of fibre with associated declines in over-all fibre and $\mathrm{OM}$ digestibilities.

In contrast to these values, the results of Thomson et al. (1972) for processed lucerne, showed grinding and pelleting to have no effect on faecal output of fibre or OM. Thus, despite an almost $100 \%$ increase in the calculated amount of potentially-digestible fibre at the duodenum on the pelleted lucerne diet compared with the chopped diet, with the magnitude of the increase being similar to that observed for Italian ryegrass in this study, all the potentially digestible fibre presented to the intestines was digested in the caecum and colon. This over-all effect appears to be a distinctive characteristic of legumes with many studies (Osbourn et al. 1981), confirming that grinding and pelleting has a negligible effect on over-all digestibility, unlike the large depressions often seen on pelleted grass diets (Heaney et al. 1963). It is difficult to offer a tenable explanation for this effect. It would not appear from the information available that the amount of potentially digestible fibre presented to the caecum is any greater on pelleted grasses than pelleted legumes. It is interesting to note, however, that the amount of $\mathrm{N}$ digested in the caecum appears to be greater on dried legumes. For early cut grass, Beever et al. (1972) and Coehlo da Silva, Seeley, Beever et al. (1972) recorded a value of $2.6 \mathrm{~g} \mathrm{~N} / \mathrm{kg}$ OM intake, whereas for lucerne (Thomson et al. 1972; Coehlo da Silva, Seeley, Thomson et al. 1972) the mean value was $5.6 \mathrm{~g} / \mathrm{kg} \mathrm{OM}$ intake. For dried red clover, Beever, Thomson \& Harrison (1971) observed a value of $3.5 \mathrm{~g} / \mathrm{kg}$. The absence of ileal data in the present study prevents similar direct 
estimates being made for Italian ryegrass and timothy, but assuming a modest availability of duodenal $\mathrm{N}$ within the small intestine of $68 \%$, a mean value of $1.9 \mathrm{~N} / \mathrm{kg} \mathrm{OM}$ intake was obtained. Such data tend to suggest that the increased $\mathbf{N}$ digestion in the caecum on legume diets may be one possible cause of the enhanced fibre digestion seen on pelleted legumes.

\section{Effect on over-all nutrient supply}

Despite reductions in the rumen production of VFA as a result of grinding and pelleting, there was no indication of a marked shift in VFA molar proportions, unlike earlier studies (Moore, 1964) which have suggested elevated propionate proportions on pelleted diets as one possible explanation for the enhanced energy utilization seen on such diets. In this study, both pelleted diets had very similar molar proportions of propionate to those recorded on the respective chopped diets, whilst there was some indication of a small increase in butyrate proportions at the expense of acetate, but this observation was of no biological significance.

The most dramatic changes due to pelleting occurred in the absorbed energy: protein value. Using similar procedures to those adopted earlier by Beever et al. (1976) it was indicated that " total absorbed energy (TAE) fell as a consequence of pelleting from a mean value of $12.7 \mathrm{MJ} \mathrm{TAE} / \mathrm{kg} \mathrm{DM}$ (chopped) to $11.6 \mathrm{MJ} \mathrm{TAE} / \mathrm{kg} \mathrm{DM}$, with Italian ryegrass being superior to timothy by $10-15 \%$ on both physical forms. However, the proportion of absorbed protein in the TAE was increased by pelleting by $18 \%$ on the Italian ryegrass diet (IC 7.8, IP 9.2 g absorbed protein/MJ TAE) and $13 \%$ on the timothy diet (TC 9.2, TP $10.4 \mathrm{~g}$ absorbed protein/M.J ME), due to the substantial increases in the amount of undegraded dietary protein (UDP) entering the small intestine. In relation to the absorbed protein requirements suggestied by Egan \& Walker (1975), all four diets appear capable of sustaining the protein demands of all cattle over $400 \mathrm{~kg}$ live weight, gaining up to $1 \mathrm{~kg}$ live weight/d, or younger cattle gaining up to $0.25 \mathrm{~kg} / \mathrm{d}$. For young lambs, or young cattle gaining at higher rates, where the need for UDP has been established, then either of the pelleted diets or diet TC would appear most suitable. Thus, it would appear that pelleting provides a means of increasing protein supply to the animal, through enhanced flows of UDP, and when fed in conjunction with cereals, such diets may be of great value in overcoming likely protein deficiencies. Furthermore, such changes in nutrient supply as have been observed in this study provide some explanation of the improvements in the efficiency of utilization of metabolizable energy which have been observed on pelleted diets (Blaxter, 1973; Thomson \& Cammell, 1979).

The authors wish to acknowledge the veterinarian skills of Mr A. R. Austin, maintenance of the animals by Mr A. P. Fleet, chemical analyses by Mr R. J. Barnes, Mr R. B. Marshall, Mr R. J. Saynor, Miss R. L. Nixon and Mrs A. S. Keene and statistical advice by Mr M. S. Dhanoa. The Grassland Research Institute is financed through the Agricultural Research Council.

\section{REFERENCES}

American Society of Agricultural Engineers (1967). Yb. Am. Soc. agric. Engrs., p. 301.

Balch, C. C. (1950). Br. J. Jutr. 4, 361.

Baldwin, R. L., Lucas, H. L. \& Cabrera, R. (1970). In Physiology of Digestion and Metabolism in the Ruminant, p. 313 [A. T. Phillipson, editor]. Newcastle-upon Tyne: Oriel.

Beever, D. E., Coehlo da Silva, J. F., Prescott, J. H. D. \& Armstrong, D. G. (1972). Br. J. Nutr. $28,347$.

Beever, D. E., Harrison, D. G., Thomson, D. J., Cammell, S. B. \& Osbourn, D. F. (1974). Br. J. Nutr. $32,99$.

Beever, D. E., Terry, R. A., Dammell, S. B. \& Wallace, A. S. (1978). J. agric. Sci. Camb. 90, 463.

Beever, D. E., Thomson, D. I. \& Cammell, S. B. (1976). J. agric. Sci., Camb. 86, 443.

Beever, D. E., Thomson, D. J., Cammell, S. B. \& Harrison, D. G. (1977). J. agric. Sci., Camb. 88, 61. 
Beever, D. E., Thomson, D. J. \& Harrison, D. G. (1971). Proc. Nutr. Soc. 30, 86A.

Beever, D. E., Thomson, D. J., Pfeffer, E. \& Armstrong, D. G. (1971). Br. J. Nutr. $26,123$.

Bjarnson, J. \& Carpenter, K. J. (1969). Br. J. Nutr. 23, 859.

Bjarnson, J. \& Carpenter, K. J. (1970). Br. J. Nutr. 24, 313.

Black, J. L., Beever, D. E., Faichney, G. J., Howarth, B. R. \& Graham, N.Mc. (1980/81) Agric. Systems 6, (In the Press.)

Blaxter, K. L. (1973). Proc. int. Congr. Green Crop Drying, Oxford, p. 64.

Blaxter, K. L., Graham, N.Mc. \& Wainman, F. W. (1956). Br. J. Nutr. 10, 69.

Brown, G. F., Armstrong, D. G. \& MacRae, J. C. (1968). Br. Vet. J. 124, 78.

Cammell, S. B. (1977). Tech. Rep. Grassld Res. Inst. No. 24.

Campling, R. C., Freer, M. \& Balch, C. C. (1963). Br. J. Nutr. 17, 263.

Canaway, R. J. \& Thomson, D. J. (1977). Tech. Rep. Grassld Res. Inst. No. 23.

Christian, K. R. \& Coup, M. R. (1954). N.Z. Jl. Sci. Tech. A36, 328

Coehlo, da Silva, J. F., Seeley, R. C., Beever, D. E., Prescott, J. H. D. \& Armstrong, D. G. (1972a). Br. J. Nutr. $28,357$.

Coehlo da Silva, J. F., Seeley, R. C., Thomson, D. J., Beever, D. E. \& Armstrong, D. G. (1972b). Br. J. Nutr. $28,43$.

Egan, A. R. \& Walker, D. J. (1975). Proc. 3rd Wld. Conf. Anim. Prod. Melbourne, p. 551.

Harrison, D. G. (1974). Newslett. appl. Nucl. Meth. Biol. Agric. no. 3, p. 8.

Heaney, D. P., Pidgen, W. J., Minson, D. J. \& Pritchard, G. I. (1963). J. Anim. Sci. $22,752$.

Jarrige, R., Demarquilly, C., Journet, M. \& Berranger, C. (1973). Proc. lst int. Congr. Green Crop Drying, Oxford, p. 99.

MacRae, J. C. \& Armstrong, D. G. (1969). Br. J. Nutr. 23, 15.

Maeng, W. J. \& Baldwin, R. L. (1975). J. Dairy Sci. 59, 643.

Moore, L. A. (1964). J. Anim. Sci. 23, 230.

Moore, S. (1963). J. biol. Chem. 238, 235.

Morant, S. V., Ridley, J. L. \& Sutton, J. D. (1978). Br. J. Nutr. 39, 451

Osbourn, D. F., Terry, R. A., Outen, G. E. \& Cammell, S. B. (1976). Proc. 12th int. Grassld Congr. Moscow, sect. 5, p. 514.

Osbourn, D. F., Terry, R. A., Spooner, M. C. \& Tetlow, R. M. (1981). Anim. Sci. Fd Technol. (In the Press.)

Outen, G. E., Beever, D. E., Osbourn, D. F. \& Thomson, D. J. (1975). J. Sci. Fd Agric. 26, 1381.

Rodriguez, C. B. \& Allen, N. N. (1960). Can. J. Anim. Sci. 40, 23.

Thomson, D. J., Beever, D. E., Coehlo da Silva, J. F. \& Armstrong, D. G. (1972). Br. J. Nutr. $28,31$.

Thomson, D. J., Beever, D. E., Latham, M. J., Sharpe, M. E. \& Terry, R. A. (1978). J. agric. Sci., Camb. $91,1$. Thomson, D. J. \& Cammell, S. B. (1979). Br. J. Nutr. 41, 297.

Van Soest, P. J. (1963). J. Ass. off. agric. Chem. 46, 825.

Van Soest, P. J. \& Wine, R. H. (1967). J. Ass. off. Analyt. Chem. 50, 50.

Wainman, F. W. \& Blaxter, K. L. (1972). J. agric. Sci., Camb. 79, 435.

Weller, R. A., Gray, F. V., Pilgrim, A. F. \& Jones, G. B. (1967). Aust. J. agric. Res. 18, 107.

Wilkins, R. J. (1969). J. agric. Sci., Camb. 73, 57. 